\title{
Gündelik Hayatta Benlik Sunumunun Dijital Oyunlar Üzerinden İncelenmesi "The Sims 4 Oyunu Örneği’"
}

\author{
Öğr. Gör. Nurgül Soydaș ${ }^{*}$ \\ Doç. Dr. Nilnur Tandaçgüneş Kahraman ${ }^{2}$
}

Gelis tarihi: 11.01 .2020

Kabul tarihi: 07.03.2020

\section{Atıf bilgisi:}

IBAD Sosyal Bilimler Dergisi

Sayı: $7 \quad$ Sayfa: 235-252

Yıl: 2020 Dönem: Yaz

This article was checked by Turnitin.

Similarity Index $11 \%$

Bu makalede araştırma ve yayın etiğine uyulmuştur.

\section{Düzce Üniversitesi, Türkiye, nurgulsoydas@duzce.edu.tr, ORCID ID 0000-0003-1345-8718}

2ं̇stanbul Üniversitesi, Türkiye, nilnur.tandacgunes@istanbul.edu.tr, ORCID ID 0000-0001-5554-3668

\footnotetext{
* Sorumlu yazar
}

\begin{abstract}
ÖZ
Toplumsal bir varlık olan insan, biyolojik gelişimini tamamlarken, toplumsal normlarla bütünleşmekte ve kişiliği bu toplumsallaşma sürecinde oluşmaktadır. İletişim, kişinin kendini gerçekleştirebilmesi ve toplumsallaşabilmesi için hayati önem taşımaktadır. Özellikle kişi, iletişim aracılı̆̆ıyla kendi fikirlerini ifade edebilme, diğerleriyle paylaşabilme ve kıyas yapabilme olanağı bulur. Çünkü iletişimle yalnızca anlamak, anlaşmak ve anlaşılmaktan öte, kendini ifade edebilme ve başkalarını anlayabilme mümkündür. Yeni ilişkilerin kurulması ve olan ilişkilerin devam etmesi iletişimle sağlanır. İletişim sayesinde kurulan ilişkiler bir yaşam pratiği kazandırmakta ve gündelik hayata dair anlayışı da belirginleştirmektedir. Gündelik hayat ve yaşam pratiği yönünden iletişimin kendisi kadar iletişim araçları da etkin bir rol oynamaktadır. Yeni iletișim ortamlarının getirisiyle iletişim ve ilişkilerin doğası da değişmiştir. Web 2.0 ile birlikte yeni kitle iletişim ortamlarında eğlence işlevinin vurgusu artarak, hayatımızla ilgili her alanda etkili uygulamalar günlük hayatın vazgeçilmezi olmuştur. İnsan hayatının önemli bir parçası olan oyunun, günümüz teknolojisine eş olarak dijitalleşmesi, oyun karakterleri ve alanlarının/mekânlarının yeniden sorgulanmasını da beraberinde getirmiştir. Dijital oyunların dijital ortamlarda en çok tercih edilen pratiklerden biri haline gelmesi en temel göstergedir. Sosyal yaşamda ve kişisel gelişimde etkili olan dijital oyunlar benlik ve benlik sunumunda da önem arz etmektedir. Bu oyunlarda kimlikler ve hayatlar üretmekte, bireyler bedenlerinden ayrlarak dijital ortamda yeni bir hayat, yeni bir kimlik kurmakta ve sanal bir uzamda dijital bir kültürü türetmektedir.Bu çalışmada, gündelik hayatta benlik sunumu olgusu, Goffman'ın Gündelik Hayatta Benliğin Sunumu kavramı referans alınarak, dijital oyunlar merkezinde benliğin sanal sunumu incelenmiştir. Çalışmanın araştırma evreni The Sims 4 oyunu olarak belirlenmiştir. Oyun, gündelik yaşam pratiklerinin simüle edildiği bir evrene sahip olması ve benlik sunumu teorisine örnek teşkil etmesi nedeniyle seçilmiştir. Türkiye'de daha önce The Sims 4 ve benlik sunumu üzerine yapılmış akademik bir yayın olmaması araştırmanın önemi vurgulamaktadır.
\end{abstract}

Anahtar Kelimeler: Benlik Sunumu, Dijital Oyunlar, Erving Goffman, The Sims 4. 


\title{
Investigation of Self Presentation in Digital Games in Everyday Life "The Sims 4 Game
} Example"

\author{
Lec. Nurgül Soydaş ${ }^{{ }^{*}}$ \\ Assoc. Prof. Dr. Nilnur Tandaçgüneş Kahraman²
}

First received: 11.01 .2020 Accepted: 07.03.2020

\section{Citation:}

IBAD Journal of Social Sciences

Issue: 7

Pages: 235-252

Year: $2020 \quad$ Session: Summer

This article was checked by Turnitin. Similarity Index 11\%

\section{${ }^{1}$ Düzce University, Turkey, nurgulsoydas@duzce.edu.tr, ORCID ID 0000-0003-1345-8718}

2İstanbul University, Turkey, nilnur.tandacgunes@istanbul.edu.tr, ORCID ID 0000-0001-5554-3668

* Corresponding Author

\begin{abstract}
As a social being, human being completes his biological development, integrates with social norms and his personality is formed in this socialization process. Communication is vital for self-realization and socialization. In particular, the person has the opportunity to express his / her own ideas, to share with others and to compare by means of communication. Because communication is more than just understanding, understanding and understanding, it is possible to express oneself and to understand others. The establishment of new relations and the continuation of the relations are ensured through communication. The relations established through communication give a life practice and make the understanding of daily life clearer.In terms of daily life and life practice, communication tools play an active role as well as communication itself. With the return of new communication environments, the nature of communication and relations has also changed. With Web 2.0, the emphasis on entertainment function in new mass media has increased and effective applications in every field of our lives have become indispensable in daily life. The digitalization of the game, which is an important part of human life as the technology of today, has brought about the questioning of the game characters and fields / spaces again. The most important indicator is that digital games become one of the most preferred practices in digital environments. Digital games which are effective in social life and personal development are also important in self and self presentation. In these games, they produce identities and lives, individuals separate from their bodies, establish a new life, a new identity in the digital environment and derive a digital culture in a virtual space.In this study, the concept of self-presentation in daily life, the virtual presentation of self in the digital games center is examined with reference to Goffman's Presentation of Self in Everyday Life. The universe of this research is The Sims 4 game. This game has been chosen because it has a universe in which everyday life practices are simulated and it sets an example to the theory of self-presentation. Turkey before The Sims 4, and a lack of academic publications made on self-report emphasizes the importance of research.
\end{abstract}

Keywords: Self Presentation, Digital Games, Erving Goffman, The Sims 4. 


\section{GİRIŞ}

Huizinga'nın esere adını veren "Oynayan insan" ifadesi, oyunun toplumsal işlevini imlemektedir. Öyle ki toplumsal hayat oyunlar tarafindan temsil edilen yüksek saygınlık veren biyoloji-üstü biçimler olarak ortaya çıkmaktadır. Topluluk ise bu oyunlarla, hayatı ve dünyayı yorumlama biçimini ifade etmektedir (Huizinga, 2006: s. 70). Bu da bizlere kültürün ilk aşamalarından itibaren oyunun çizgiselliğinde geliştiğini gösterir. Kültür ile oyunun bu ikili birlikteliğinde oyun, nesnel olarak gözlenebilen ve somut biçimde belirlenen ilksel unsuru meydana getiren bir fonksiyona sahiptir.

Oyun, yarışma, temsil, öğrenme ve hoşça vakit geçirme biçimi olarak her koşulda yaşamsal alanda etkindir. Oyunun genel karakteristiklerine bakıldığında gerilim ve belirsizlik başı çekmektedir. Ayrıca başarı olgusunu da beraberinde taşır. Oyunun zorluk oranına göre seyircilerin gerilimi artar. Eğer oyun bir estetik veya güzellik üretirse kültürel açıdan daha büyük değer kazanmaktadır (Wang; Sun, 2011,s. 115). Oyun, taşıdığı fiziksel, entelektüel, ahlaki ve ruhani değerler sayesinde kültüre dönüşür. "Kazanacak bir şey var" ifadesi Huizinga'ya göre oyunun özünü ifade eder (Huizinga, 2006, s. 75). Bu bazen golle gelen bir zaferdir, bazen bir kupa ya da ödüldür. Ancak kazanılacak şeyin illaki maddi bir değere sahip olması gerekmez. Önemli olan "idealleşmiş başarı" duygusunun kendisini tatmaktır. Başarı en önemli unsurudur (Henricks, 2011, s. 157-185). Bu nedenledir ki kazanma fikri oyunla çok sıkı ilişki içindedir. Kazanmak, oyunun sınırlarını aşarak beraberinde itibar ve onur duygusu getirir. Oyunsal alana konulan simgesel nesneye Latince vadium (güvence) denmesinin sebebi de budur. Bu nedenle de "kazanç" olgusu semantik olarak ekonomik mübadele alanına ait bir terim iken oyun alanına da dahil olmuş olur. Benlik sunumu inşasına imkan veren oyunlarda ise kazanılan "ideal benlik" tir (Tandaçgüneş, 2015, s. 253-281).

Oyunun; öğrenme, sosyalleşme, eğlence ve dinlenme aracı olarak geçmişten günümüze oldukça önemli kültürel işlevlere sahip oluşu, yaygın tanımıyla sadece çocukluğa özgü bir ifade olmaktan ötesi olduğunun göstergesidir. Bu bakış açısı, yeni bir etkinlik alanı olarak dijital oyunların, günümüzde bireylerin günlük yaşam pratiklerinde ne kadar önemli bir alana sahip olduğunu anlamayı kolaylaştırır. Vaktinin büyük bir bölümünü sanal ortamdaki bu oyunlarda geçiren günümüz modern bireyleri, oyun etkinliği esnasında sadece eğlence ve zevk gibi duygusal unsurları deneyimlemez. Sanal mecrada oyun oynamaya başlayan birey için bu sanallık, kimi zaman gerçek dünyadan bir kaçış iken, kimi zaman hayalindeki kimliğe büründüğü ve yaşamak istediği hayatta ideal benlik sunumun ifadesi haline gelmektedir (Yurdigül ve Sekmen, 2015, s. 131). Bu anlamda internet ortamında sanal kimliklerin yaratılmasında ve benliğin sunumunda iki ayrı olguyla karşılaşmaktayız. Birincisi, sanal kimliğin gerçek dünyadaki uzantısı ile birlikte incelenmesiyken; ikincisi yalnızca sanal dünyadaki kimliğin incelenmesi şeklindedir (Binark, 2007, s. 24). Dijital oyunların etkilemek, iletmek boyutu taşıması ve bunu da -işteş' likle yaparak karşılılık kazandırması (iletişim-etkileşim), kişilerin gerçek dünyada olmak isteyip de olamadıkları her şeye ulaşma imkânı sağlaması, kazanma tutkusunu, başarı ve sahip olma güdüsü oluşturması dijital oyunları daha önemli bir noktaya taşımaktadır (Ögel, 2012). Bu çalışmada Erving Goffman'ın benlik sunumu kavramı, dijital oyunlarda benlik sunumunun değerlendirilmesinde referans alınmıştır. (Mead, 1934; Goffman, 1959). Bu bağlamda ilgili literatür taraması yapıldığında rastlanılan Sait Gülsoy'un dijital oyunlar ve benlik sunumu kullanımını tartıştığı bildirisindeki, video oyunlarının sosyolojisine yönelik kavramsallaştırma önerisi bu çalışmanın ortaya çıkışında etkili olmuştur.

Öyle ki "Gofmann'a göre hepimiz bir birey olarak doğarız, kişilik sahibi oluruz ve sonunda kişi olarak yaşamımızı sürdürürüz. Kişi üzerine düşen bu görevde bir oyuncu kişiliği bile sergilese özdeşim kurduğu kadar, kendi sergilediği performansa inanacaktır. Benlik sunumunun ana yapı olarak oyun şeklinde görülme nedeni, oyuncu kişiliği ile bireyin kendi kişiliğinin birbiriyle ne kadar örtüştüğüdür. Çünkü günlük hayatta benlik sunumu olarak sergilenen davranışlar performans olarak görülmekte ve bütün bu performanslar toplumsal rolleri içermektedir. Bu performansların sergilendiği alanlar toplumsal uzamla eş düzeydedir" (Gülsoy, 2015, s. 1074-1075).

$\mathrm{Bu}$ bağlamda Goffman, benlik sunumu olarak kavramsallaştırdığı dramaturji ile 'oyuncu benliğin sunumu', 'takım performansları', 'oyun takımları', 'oyuncu kişiliğin performansı', 'sanal vitrinler', 'oyuncunun takıma katılım performansı' video oyunları üzerinde bu kavramları kullanmanın yolunu açmaktadır. Bu çalışmada, bütün dünyada dijital oyunlar arasında popüler olan ve en çok serisi olan The 
Sims 4 dijital oyunu üzerinden inceleme yapılmıştır. Bu oyunun seçilmesinde hayat simülasyon oyunu olması ve bu çalışmanın da gündelik hayatta benlik sunumunu içermesi nedeniyle özellikle etkili olmuştur.

\section{BENLİK KAVRAMI}

"Bir bilinçlilik hali olarak kişinin kim ve ne olduğu, etrafındakiler tarafından nasıl bilindiği sorusunun yanıtı" olarak tanımlanan (TDK Ruhbilimleri Sözlüğ̈̈) benlik, iletişim süreci içinde oluşan bir kavramdır. İnsanın kendine ve diğerlerine, başkalarının gözüyle bakabilmeyi öğrenebilmesi olarak özetlenebilir (Ertürk, 2010, s. 93). Çoğunlukla psikolojik bir terim olarak yorumlanan benlik, yalnızca psikolojinin kavramlarıyla değerlendirilemez; toplumsal, kültürel etkenlerin de değerlendirilmesi gerekmektedir. Benlik sosyal hayatta kazanılan bir edinimdir. Öyle ki dünyaya geldiğimiz an itibariyle dünyayı tanımaya çalışırız. Dünyayı tanımaya çalışırken kendimizi ve etrafımızdakileri de tanımlayıp ona uygun şekilde kendimizi konumlandırmaya çalışırız. Henüz çocukken dünyayı ve etrafımızı tam tanıyamadığımız bir süreç söz konusudur. Yavaş yavaş toplumsal hayata dâhil olmaya başlayıp etrafımızı anlamlandırmaya çalıştı̆̆ımız dönemler tam olarak ayrımı göremediğimiz dönemler olarak ifade edilmektedir. Toplumsal hayatta bir yer edinmeye başladıkça önce kendimizi, sonra etrafimızı tanımayla toplumsal hayatta var olmaya çalışırız. Bu süreçte de ilk olarak aile kavramını öğrenir, ayrımlar geliştiririz, ardından birlikte yaşadığımız insan topluluklarını, mahalleyi, eğitim gördüğümüz ortamları öğrenir, bu ortamlara dâhil oluruz. Ortamların getirisi olan davranışları da gerçekleştirmeye başlarız (Güney, 2016, s. 223).

Diğer bir tanımla benlik denilen kavram, kişinin kendisini algılama biçimidir. Özellikle psikolojik olarak kendini algıladığı ve sosyal hayatta tecrübe edindiği bir kavram olarak ifade edilir. Çünkü kişi hayatında ben ve ötekiler diye bir kavram oluşturur. Kendi ve ötekiler için hangi davranışları ne şekilde sergileyeceğini öğrenir, buna uygun davranış örüntüleri geliştirir (Mutlu, 2012, s. 45). Bütün bunlara bakılarak benlik kavramını incelerken kişinin davranışlarının tamamının gözlemlenmesi ve yorumlanması gerekliliği ortaya çıkmaktadır. Kişinin kendi fiziksel özellikleri, aile yapısı, kimliği, tutum ve davranışları, becerileri ve ilgileri, ruhsal durumları ve ötekilerle kurduğu iletişimleri de benlik inşası sürecinde etkilidir. Bahsi geçen bütün evrelerin değişim, dönüşüm ve gelişim geçirebileceği durumları göz önünde bulundurularak tanımın çerçevesi ilişkiler bağlamında yorumlanabilir. Diğerleriyle ve kişinin kendiyle olan iletişimi benliği de etkilemektedir. Benlik bireyi içeren; ama bireylerin birbiriyle olan iletişimleriyle şekillenen bir süreçtir. Birey bu inşa sürecinde kendisi dışında kalan "ötekiler" ile ilgili fikir, duygu, davranış ve deneyimleri de referans alır. Bu süreçteki ortak nokta iletişim ve etkileşimden beslenerek değişim gösterebilecek olmasıdır. Benlik, kişiyi ötekilerden ayıran bütün her şeydir. Bu bakış açısıyla, sosyal hayatın en ufak birimi olan aileden, toplumu meydana getiren bütün unsurlara kadar her detay benlik oluşumunda ayrı bir role sahiptir denilebilir.

\subsection{Benlik, Kimlik İnşası ve Benlik Sunumu}

Anthony Giddens, psikolojik süreçlerin ve ihtiyaçların dışında, benliğin oluşumunu desteklediği ya da onu tehdit ettiği hallerde toplumsal olanın da etkili olduğunu söyler. Giddens'e göre modern çağda ilk kez "benlik" ve "toplum" kavramları küresel bir ortamda karşılıklı yoğun bir ilişkiye girmiştir. Yani denilebilir ki çoğunlukla psikolojiye ait bir terim şeklinde kabul edilen benlik, yalnızca psikolojinin kavramlarıyla değerlendirilemez; toplumsal, kültürel etkenlerin ve iletişimin de değerlendirilmesi gerekir. (Giddens, 2004, s. 42). Bu nokta toplumsallaşma sürecinde oluşan kimlik kavramına da değinmek gerekmektedir. Kimlik insanın toplumsal yaşamda var olabilmesi için inşa edilen, benliği içine alan, onu sınırlandıran ve toplumla uyumlu hale getiren bir kavramdır. Benliğimizi günlük yaşamda sunma biçimimiz, kimliğimizle olur. Çünkü insan içinde bulunduğu her sosyal ortama bir anlam yükler ve bu sosyal ortama uygun davranışlar geliştirir. Kişi, yaratacağı izlenimi şekillendirmek için davranışlarını kontrol altında tutmaya çalışır (Giddens, 2010, s. 130).

İnsanlar doğar doğmaz bir benlik kazanmazlar. Doğdukları yapı içerisinde o yapının özelliklerinden etkilenerek benlikleri şekillenmeye başlar. Toplumsal varlık olan insan dahil olduğu sosyal yapının içerdiği sistemin toplumsal, kültürel ve ekonomik süreçlerinin de içinde olduğu bir bütünleşmeyle benliğini inşa eder. İnsanın sosyal varlık olarak sosyalleşme sürecinde toplumda yaşanan birçok değişimden etkilenmesi de olağandır. Bütün bu olağanlığın yanında etkileşime geçerek etkilendiği gibi, 
birçok şeyi de etkilemesi insanı diğer canlılardan ayırmaktadır. Öyle ki ötekilerden etkilenme ve ötekileri etkileme sürecinde ötekileri denetim altında tutma, etkileme ve izlenimlerini yönetme istekleri de bu durumu olağanlaştırmaktadır. Benlik sunumu ötekilerine yönelik oluşturulan izlenimi denetleme olarak adlandırılır (Taylor, Peplau ve Sears, 2007, s. 132).

Goffman'ın, bireyin ötekilerle bir arada olduğunda, ötekilerin bireyle ilgili bilgi edinme çabasına giriştikleri ya da var olan edinilmiş bilgilerini kullanarak etkileşime geçtiklerini ifade etmesi (2004), Giddens' in "Kişinin yalnızca kamusal alanda etkileşim kurması ve iletişime geçmesi yeterli olmaz. Ayrı yerlerde ayrı anlarda da onaylanan davranışları devam ettirmesi kişiden istenir (2010, s. 133)" sözlerinin tamamlayıcısı gibidir. Çünkü benlik sunumu, bireyin kendiyle ilgili paylaştığı bilgileri ve sergilediği performansları ötekilere aktarma ve bunu sürdürme eylemi olarak değerlendirilmektedir. Benlik sunumu, nasıl giyildiğinden, araba sürüş tarzına, öteki insanlara yönelik korkuları saklamak için sergilenen davranışlara, yürüyüş tarzına kadar detaylı bir süreci içerir. Değişen ve gelişen olanaklar doğrultusunda yeni iletişim teknolojilerinin sağladığı yeni iletişim olanakları benlik sunumu için yeni bir ortam olarak hayatlara dâhil olmuştur (Baumeister ve Bushman, 2014, s. 106). Denilebilir ki bireylerin benlik sunumları bir ihtiyaçtır, bu ihtiyaçlarını da gündelik yaşantılarındaki sosyallaşme süreçlerinde karşılaştıkları gerçek veya sanal bütün ortamlarda karşılamaktadırlar. Bir bireyin, kendisi dışında olan çevresi tarafından algılanma şekli benlik sunumu olarak tanımlanmaktadır (Leary, 1996). Bireyin, kendini ifade etmede sergilediği davranışların planlı olması, bireyler arası ve toplumsal ilişkilerin temelidir (Bacanl1, 1990). Bireyler, benlik sunumlarında birçok yöntemi kullanabilmektedir. Öyle ki hiç tanımadığı birine hiç olmadığı biri gibi davranabilir, demografik, sosyal ve bireysel bilgilerini çarpıtabilir, değişikliğe uğratarak sunabilir. İletişimini de bu temel üzerine şekillendirebilir. İletişim süreci senaryolaştırılarak kimlikler ve benlikler inşa edilebilir(Timisi, 2003, s. 172). Kitle iletişim araçları birçok toplumda birçok farklı amaçlar için kullanılmaktadır. Gelişen teknoloji, değişen çağ ve kitle iletişim araçlarındaki farklılıklar sosyal hayatta yer alan ihtiyaçlar da düşünüldüğünde kitle iletişim araçlarını, araçları kullanma şekillerini, bireylerin huylarını, günlük rutinlerini ve birbiriyle ilişkili birçok şeyi de dönüştürmektedir (Soydaş, 2018, s.203). Bütün bu bilgiler 1şı̆̆ında benlik inşası ve benlik sunumlarının da benzer süreçlerden etkilendiği ifade edilebilir.Son yıllarda dijital sosyal ă sitelerinin kullanımının yaygınlaşmasıyla insanlar, kendilerini başkalarına çeşitli yönleriyle sunabilecekleri yeni platformlara kavuşmuştur. Günümüzün insanları Facebook, Instagram gibi sosyal ağ sitelerinde bir yandan başka kişilerin paylaşımlarını takip ederler, bir yandan da kişisel sosyal ağ profillerinde kendileri hakkında paylaşımlarda bulunarak benliklerini başkalarına sunarlar (Young ve Quan- Haase, 2009). Kişilerin sosyal ağlarda kendileriyle ilgili bilgiler paylaşırken benliklerini çeşitli açılardan sundukları bilinmektedir: Sosyal ağlarda isterlerse gerçek benliklerini sunabilirler; isterlerse yüz yüze ortamlarda sergilememiş oldukları yeni yönlerini keşfedip sunabilirler ya da yine eğer isterlerse, aslında hiç sahip olmadıkları özelliklere sahipmiş gibi kendilerini tanıtıp sosyal ağları başkalarını kandırmak için kullanabilirler (Michikyan, Subrahmanyam ve Dennis, 2015).

Benlik algısı, bireyin kendini algılamaya başlaması ve ötekilerin de onun hakkındaki görüşleriyle şekillenen bir süreçtir. Bu süreçte, birey diğerlerine yönelik olumlu bir imaj oluşturarak, bu olumlu imaj1 sürdürmek ve devamlılığını sağlamak adına davranışlarda bulunmaktadır. Gerekirse birey kendini rol yaparken de bulabilmektedir. Diğerleri tarafından onanmak için rol yapmak birey için olağan bir durum olarak karşılanabilmektedir. Birey bunu günlük yaşantısını sürdürmek ve ötekiler arasında yer edinmek için kendini mecbur hissedebilmektedir. Goffman'ın “Gündelik Yaşamda Benlik Sunumu” adlı eseri, bireylerin günlük hayatlarında benliklerini sergileme şekillerini, muhtemel davranışlardan hangisini sergileyeceklerine dair seçimlerini ve benlik sunumuna dair görüşlerini anlamak için bu çalışmanın temel izleği olacaktır.

Oyuncuların kendilerini ifade etmeyi bıraksalar bile ifade yaymayı bırakamayacakları (Goffman, 2004, s. 109) sözü, Goffman'ın çalışmasının önemli vurgularından biridir. Goffman, tiyatro perdesi metaforu ile performans düşüncesini gündelik durumlar içinde "bireyin kendini başkalarına sunuş tarzı, başkalarının onun hakkında (zihinlerinde) biçimlendirdikleri izlenimleri ve onların huzurunda yapabileceği ve yapamayacağı şeyleri düzenleyiş ve kontrol ediş biçimi" olarak tanımlamakta ve hayatla tiyatronun kıyaslamasını yapmaktadır. Goffman'a göre bireyler, ötekilerine yönelik inşa etmek için izlenimleri denetlemek için sergiledikleri eylemlerde bulunur. Bu eylemlerle kendini ortaya koyma durumuna 
"Benlik Sunumu" (self-presentation) denmektedir. Kendini ortaya koyma, kendini gerçekleştirme ve toplumsal hayatta var olmayı sağlar (Tedeschi, Lindskold ve Rosenfeld, 1985).

Bireylerin benliğini sergilediği toplumsal alanları Goffman sekiz sınıfa ayırır. Bu süreçleri anlamak için park, bank ve restaurant gibi bireyle birlikte hareket eden "ben merkezli özel alanlar"in varlığından bahseder. Bunlar genellikle uzun dönemli alanlardır. Birincisi, kişinin kendisinin bulunduğu ortam olan onu memnuniyetsizlik göstermeye ve hatta bazen geri çekilmeye ittiği bazen de sıkıştırılmış hissettiği alanları ifade eden "kişisel mekan"lardır. Plaj havlusunun üzeri, telefon kulübesi, manzaralı bir masa veya boş bir baraka gibi durduğu alanları ifade eden "park yeri"leri bir diğeridir. Bireyin etrafinda/önünde bulunan alan olarak, sergideki bir resmin önünden geçerken ötekilere göstermesi gereken saygıyı sergilediği yerler ise "kullanım mekanı"nı ifade eder. Yaş, cinsiyet veya etnisiteyle kategorize edilen alanları ise "sıra mekanı" olarak tanımlar. Bedeni kaplayan giysiler ve bedenin farklı uzuvlarının taşıdığı sembolik anlam "kılıf " olarak tanımlarken bunların sergilendiği alanları "özel mekanlar" olarak tanımlar. "Sahip olunan mekan"lar ise, bireyin benliğiyle özdeşleşme kurduğu, kullanımına ait bütün nesneleri kapsayıcı veya bedenini süslemek için kullandığı bütün kişisel eşyalarını ifade eden kapsayıcı bir alandır. "Bilgi özel alanı" bireyin ötekileri etkilemek için sahip olduğu bedenin kılıfı gibi görünür olmayan; cüzdan, mektup gibi görece daha gizil objeleri ifade eder." Son olarak "Sohbet özel alanı", sınıf ve erke göre değişen alanları ifade eder. Bu alanlarda bireyin mevkii yükseldikçe benliğin, mekanların boyutu ve sınırların üzerindeki etkisi artmaktadır (Goffman, 2017, s. 54-66).

Özetle, bireyler toplumsal iletişimde etrafindakileri etkilemek ve izlenim yönetmek için roller edinmektedirler. $\mathrm{Bu}$ roller gereği performanslarını sergilemekte ve bu sergileme için "maskeler" kullanmaktadırlar. Bu maskeler birey için birer benliğe dönüşmektedir; Çünkü bireyler ayrı ortamlarda ayrı amaçlarla ayrı ayrı roller oynamak durumunda kalmaktadırlar.

\section{GÜNDELIK YAŞAMDA BENLİK SUNUMU VE DİJITTAL OYUNLAR}

İnsanlık iletişim kurmak, kendini ifade etmek, diğerleri tarafından da anlaşılır olmak için çok farklı yollar denemiştir. Bütün çabaları daha çok bireylerarasında kalmıştır. Değişen teknoloji ve gelişim gösteren hayat koşulları insana farklı kapıları aralamıştır. Özellikle yeni icatlarla ve buluşlarla bilginin kapısı aralanmış, Sanayi Devrimi bu aralanmanın başlangıcı sayılmıştır. Hayatın her alanında görülmeye başlanan değişiklik ve gelişim iletişimde de kendisini göstermiştir. Bilginin iletimi için geleneksel yöntemlerle haber kurmaya çalışan insan tellerle bağlanan yapılarla daha seri bir iletime geçiş yaşamıştır. Coğrafi zorluklar ve zaman kısıtı gelişen teknolojiyle büyük oranda aşılmaya başlanmıştır. Kablolar ve tellerle yer üstünden birbirine bağlanan iletişim ağları ilerleyen teknolojiyle görünmez bağlarla daha seri ve hızlı ulaşım sağlayacak şekilde ayrıca bir ivme kazanmıştır. Görünmeyen bu kablolar yer altından bütün dünyayı birbirine bağlayacak ve her değişikliğin birbirini etkileyeceği gibi birbirinden etkilenebileceği bir gücün de simgesi olarak toplumda yerini almıştır.

Günümüzde yaşanan teknolojik değișimler bütün iletişim terminolojisinde "yeni” ifadesiyle karșıllk bulur. Öyle ki yeni iletişim teknolojileri, insanların günlük yaşam pratiklerine de sirayet etmiştir. Bireylerin interneti, bireysel ve kamusal alan şeklinde kullanılması ve oturdukları yerden kıpırdamadan ağ üzerinden kontak kurmaları bu görüşü destekler niteliktedir (Lefebre, 2007, s. 65). Günlük yaşantının içerisinde kendini konumlandırmada birçok noktaya değinen bu teknolojik yaklaşım sayesinde, bireylerin çok sayıda bilgiyi aynı anda iletebilme ve birçok kitleye ulaşabilme gücünü elinde tutabilmesi, sadece iletmek işlevinin haricinde hiper metinselliğe uzanan bir sürecin ispatı olmuştur (Binark, 2007, s. 21).

Teknolojiyle yaşanan bu gelişim ve değişim, iletişimi, sosyal iletişimi ve kitlelerin iletişimini bile değişime uğratarak dönüşüm yaşamasını sağlamaktadır (Binark, 2007, s. 22). Sadece bilgilenme olarak değil, iletişimsel olarak da sosyal ilişkiler, arkadaşlıklar, dâhil olunan gruplar, evlilikler, ikili özel ilişkiler, benlik, kimlik, aidiyet, izlenim yönetmek (benlik sunumu) şeklinde iletişimin biçimlendiği bir başka yapıya evrilmiştir (Güçdemir, 2010, s. 39). Bu yeni ortam sadece yeni iletişim teknolojilerinin sağladığı araçlarla kalmamış, toplumsallaşma aracı olan oyun oynama güdümünde de kendisini göstermiştir. Sokak aralarında oynanan aktiviteden teknoloji uzamıyla şekillenen bir biçime bürünmüştür. Her yaştan her kesimden insanın oynadığı oyunlar çağa adını veren kavram olarak "dijital" 
ortamlarda, yeni hayatların inşası ve bu hayatların sunumu olarak da ele alınmalıdır. Gündelik hayatların teknoloji sayesinde dijitale taşındığı gündelik olanın dijitalle normalleştiği bu süreçte dijital oyunlar vasıtasıyla bireyler kimlikleri inşa edilmekte, çeşitli toplumsal gruplara üye olabilmekte, aidiyet ve benlik sunumunda bulunabilmektedir.

Günümüzde geleneksel oyun anlayışı yerini yeni iletişim teknolojileriyle birlikte dijital ortamlara bırakmaktadır. Bu yeni ortamların getirisi olan oyun kavramı "dijital oyun" olarak ifade edilmektedir. $\mathrm{Bu}$ bağlamda dijital oyun kavramının, gündelik yaşmadaki benlik sunuma etkisinin tam olarak anlaşılabilmesi için iletişim alanında yapılacak çalışmalar önem arz etmektedir (Turkle, 1999).

İletişim teknolojilerinin gelişimi ile birlikte bireyler zaman ve mekândan bağımsız olarak internet üzerinden çeşitli dijital oyunları farklı kişilerle oynama imkânı bulmaktadır. Teknolojinin gelişmediği zamanlarda sokakta arkadaşlarla birlikte oynanan oyunlar atık bilgisayar başında veya teknolojik cihazlarla oynanmaktadır. Oyun artık sanal bir aktivite haline gelmiştir (Meredith, 2014; Horzum, 2011). Her yaş grubundan insanın oynadığı dijital oyunlar yalnızca çocuklara özgü olmaktan çıkmıştır. Dijital oyunları oynayan kişilerin kendilerini oyun kahramanları yerine koyduğu hatta onların yaşadığı dijital ortamdaki hayatı gerçek dünyada yaşamaya çalıştıkları veya gerçek dünyada yaşayamadıkları durumları dijital ortamda yaşamaya çalıştıkları görülmektedir. Bu durum dijital oyun içeriklerinin günlük yaşantıda da önemini açıklamaya yardımcı olmaktadır.

Genel olarak bilgisayar vasıtası ile (masa üstü veya diz üstü), kollarla oluşan konsol oyunları, cep telefonları vb. elektronik cihazlarla oyun oynamak şeklinde ifade edilen dijital oyunlar (Whitton'dan aktaran Erboy ve Vural, 2014, s. 41) insanların yaşamının vazgeçilmez bir parçası haline gelmiştir. Dijital oyunların, farklı demografik özellikteki çok sayıda bireyin gündelik hayatında etkili olduğu yapılan araştırmalarla bilinmektedir. Bu durumda bireyler, dijital oyunlar içerisinde gizlenen ve farkında olmadan aşılanmaya çalışan fikirlerin etkisinde kalarak, sosyal yaşamlarının, karakterlerinin şekillenmesinde ve benlik sunumlarında büyük rol oynamaktadır (Binark ve Bayraktutan, 2008).

Dijital oyunlara olan ilgi her geçen gün daha da yoğun olmaktadır. Oyunların ses, görüntü kalitesinin yükselmesi ve oyunculara atfedilen roller bu durumları daha da etkin kılmaktadır (Argan ve Akın, 2007). Diğer bir ifadeyle teknoloji geliştikçe sanal ortamda yaşananlar gerçek yaşam ortamına birebir aktarılmakta veya gerçek yaşamda yaşanamayanlar sanal ortamda yaşanmakta ve insanları oyun oynamaya yönlendirmektedir. Dijital oyunlar özelliklerine göre; Tematik ve teknolojik özelliklerine göre Ağ, Aksiyon, Macera, Motor Sporları ve Yarış, Rol Yapma/ Canlandırma Oyunları, Simülasyon, Spor ve Strateji Oyunları olarak sinıflandırılmaktadır (Gürcan, A. v.d., 2008, s. 4).

Yapılan tanımlamaların ardından genel olarak dijital oyunların özellikleri şu şekilde sıralanabilir (Solmaz v.d., 2015, s. 80):

> Teknoloji ilerledikçe imkânların sürekli kendini yenilemesi

$>$ Oyuncunun oyun ile kendisini içselleştirmesi ve kişiselleştirmesi

$>$ Ses, görüntü efektlerinin grafik tasarımının gerçeğe yakın olması

$>$ Senaryonun oynanabilirlik düzeyi ve çoğu oyunda gerçeğe yakın olması

$>$ Tekrar tekrar oynanabilme ( oyuna kaldığı yerden devam edebilme)

$>$ Çok kullanıcı olması ve başka oyuncularla etkileşimde bulunulması

Teknolojinin uzantısı olan erişilebilirlik ve ulaşılabilirlik dijital oyun sektöründe de etkili olmaktadır. Özellikle en popüler iletişim teknolojilerinden biri olan dijital oyunlar da çevrimiçi benlik sunumu adına etkili bir iletişim yöntemi sayılabilir. İnsanların zamanlarının çoğunu dijital oyun platformunda geçirdiği düşünüldüğünde ses, söz, görüntü gibi birçok yönüyle iletişim kurulan bireylere, kendiyle ilgili imaj oluşturması, kendi kimliğini yansıtması ve benliğini sunması daha da kolaylaşmaktadır. Bu araştırmada da çevrimiçi benlik sunumunu örneklendirmek adına yoğun bir ilgiyle oynanan hayat simülasyonunu içeren bir dijital oyun seçilmiştir. 


\subsection{Erving Goffman'ın Terminolojisinden Dijital Oyunlara: "The Sims 4 Oyununa Genel Bir Bakıș}

Goffman insanların günlük yaşantılarında ötekilerle olan ilişkilerini sürdürmek ve iletişim kurmak için gündelik hayatı bir tiyatro sahnesine benzetmiştir. $\mathrm{Bu}$ davranışlara bulunanları oyuncu, sergiledikleri davranışı rol ve bunların sunumunu bir performans olarak görmüştür. Bu çalışmada, Goffman'ın terminolojisine dayanarak dijital oyunlar özelinde "The Sims 4 Oyunu" üzerinden değerlendirmek amaçlandığı için Goffman'ın teorisine daha yakından bakılacaktır. Buna göre;

1- "Performans", kişinin ötekileri etkilemeye yönelik tüm faaliyetleri;

2- "Aktör" davranış1 gerçekleştiren ya da kendine biçilen roller için performansta bulunan kişiyi;

3- "Sahne", tüm faaliyetlerin sergilendiği alanı;

4- "Seyirciler veya gözlemciler" performansın sunum esnasında o ortamda var olan ötekileri,

5- "Rol veya rutin" davranışı gerçekleştirme sunumunda gerçekleştirilecek davranış ve etkinlikleri (Goffman, 2004, s. 28) ifade eden kavramlardır.

Performans, mesajı ileten bireyin niyetli, niyetsiz bütün eylemlerini ifade etmektedir. Ötekini etkilemek, değiştirmek, bilgilendirmek veya farklı bir niyet için yapılan tüm eylemleri içermektedir. Goffman performans kavramını ve performansı sergileyen kişinin karşısındakini etkilemek ve kendisiyle ilgili olumlu imaj inşa etmek, olumsuzsa olumluya döndürmek ya da gerçek niyetinin anlaşılmasını saklamak için bunu yaptığını ifade eder. Diğer bir görüşü ise "iletişimin sürmesi ve etkileşim için kandırmak, savsaklamak, kafa karıştırmak, onanmak, meydan okumak veya alçak görmek gibi durumlar şeklinde eylemde bulunmak gibi eylemleri de dâhil etmektedir" (Goffman, 2004, s. 17). Performansın özünü öteki diye ifadelendirilen başka insanların eylemleri ve kişinin kendisine nasıl davranacaklarına dair kontrolü sağlamak ve bunu sürdürmek oluşturmaktadır. Gündelik hayatta insanlar sosyal hayatın içerisine dâhil oldukları her ortamda benlik sunumu gerçekleștirirler. Aile içindeki eylemlerinden, okuldaki eylemlerine, mahalle arasında kurdukları arkadaşlık ilişkilerinden, profesyonel ilişkiler kurdukları iş hayatlarına kadar iletişimde bulundukları her ortamda benliklerini yönetirler. Benliklerinin sunumu olarak eyleme döktükleri performanslar amaç, ortam, zaman, mevkii, kişiler ve gruplar gibi birçok yapıdan da etkilenmektedir (Goffman, 2004, s. 140). Gündelik hayatta benlik sunumuna ilişkin bu perspektif araştırma konumuz olan dijital oyunlar üzerine yerleştirildiğinde, The Sims 4 Oyunu kullanıcılarının hesaplarında oluşturmuş oldukları tüm içerikler, oyundaki karakter hakkında oluşturmuş olduğu bilgiler, sosyalleşmek için dâhil oldukları ortamlar ve diğerlerini etkilemek için sergiledikleri davranışlara karşıllık geldiği görülmektedir.

The Sims 4 Oyunu, oynayanların günlük yaşamlarında sergiledikleri bütün eylemler, oyunculara toplumsal bir çevre sunmaktadır. Ve bu sosyal çevre sanal olarak sunulmaktadır. Bu durumu da dijitalin bir izdüşümü olarak görmek yanlış olmayacaktır. Oyuna dâhil olmak için oluşturulan karakterden, karakterin oluşumunda kullanılan/ kullanılmayan bütün detaylara kadar tüm tercihler performans olarak kabul edilmektedir. $\mathrm{Bu}$ da benlik sunumu olarak yorumlanmaktadır. Kullanıcı yarattığı oyun karakteriyle, yaptığı her davranışıyla sanal ortamda dahil olduğu toplumsal yapida bir performans sergiler. Gündelik hayatta karşılaşılabilecek iletişim hataları, etkileşiminin karşılık bulmaması gibi durumlar, The Sims 4 Oyunu üzerinde sunduğu sınırsız zaman, oyunu tekrar baștan oynamak gibi bir özelliğin olması sayesinde performans sergilenmeleri sürekli düzenlenebilir. Oluşturulmak istenilen karakterin bütün detaylarının seçilerek eklenmesiyle, istenmeyenlerin önüne geçilir. Bu sayede istenilen kişilik özelliklerinin ön plana çıkması sağlanır ve kendi sanal karakterinin sanal iletişim sürdürülür.

Performansın zamanı, süresi, içeriği kullanıcının elinde olduğu için oyundaki karakter üzerinde değiştirme yapılabilmesi, performansın sergileneceği grubun kullanıcının elinde olması ve ortamın seçilebilir olması The Sims 4 Oyunu'nun tercih edilme sebeplerinin bazılarıdır. Goffman, performansın üç önemli rol üzerinden işlediğini ifade eder: performansı sahneleyenler- oyuncular, performans tarafindan hedeflenenler seyirciler ve performansta rolü olmayan- gözlemlemeyen dışarıdakiler (Goffman, 2004, s. 140). 
Bütün bu kavramları The Sims 4 Oyunu üzerinden yorumladığımızda performansı sergileyen oyuncu; dijital oyunu oynayan hesap sahibi, seyirci; oyunu oynayanın hesap oluşturduğu arkadaş çevresi ve karakterin dâhil olduğu herkes, gözlemlemeyen dışarıdakiler ise erişim hakkı verilmeyen veya The Sims 4 Oyunu oynamayan herkes olarak görülebilir.

The Sims 4 Oyunu'nu oynayan oyuncu, performans1 sergileyecek olan oyuncunun, - kullanıcinınseyircisini (izleyicisini) belirlemesinde günlük yaşantısına oranla daha etkin bir hâkimiyet oluşturur. Goffman'ın belli kişiler topluluğunun daimi bir şekilde kişilerin karşı karşıya olduğu bir olaydaki bütün iletişim ve etkileşim şeklinde ifade ettiği "karşılaşma" kavramı $(2004$, s. 27) net bir şekilde karşılayamamaktadır. Bu terim oyuncunun etkileşime geçmek adına toplumsal yaşama karıştığı kısmı içerir. Toplumsal yaşama girmeye çalışan oyun karakteri üzerinden ifade edildiğinde oyunu oynayan kişi iki ayrı özneye şahit olmaktadır: ben ve onlar (ötekiler). Özel bir iletişim kurulmadığı, etkileşime geçilmediği sürece dijital oyunda yer alan tüm "arkadaşlar", "onlar", "ötekiler" kategorisindedir. Performansın sergilendiği alan olarak sahne oluşturmaya yardımcı mobilyalar, dekor, fiziksel alan ve fiziksel alanın ardında kalan (arka plan) bütün şeyler "set" şeklinde görülmektedir (2004, s. 27).

The Sims 4 Oyunu'nda, karakterin bulunduğu bütün mekânlarda kullanılan bütün mekânlar, mobilyalar ve dekorasyon araçları, oluşturulan içerikler olarak karşılanabilir. Günlük yaşamda oyuncuların arzu ettikleri benlik görüntüsünü oluşturabilmek adına tercih ettikleri ve sergiledikleri performanslar, dijital ortamda fiziksel olarak yer almamaktadır. Bu durumu da oyun karakteri kullandığı eşyalar ve dekore ettiği ortamlarla göstermeye çalışmaktadır. Karakterin, oluşturduğu, kullandığı her şey içerik olarak karşımıza çıkmaktadır. Karakter oyunda her ne paylaşımda bulunuyorsa o şeklinde yorumlamaktadır (Schau ve Gilly, 2003, s. 385). Yaş, cinsiyet, rrk, fiziksel dış görünüş, konuşma biçimleri, vücut şekli, jest ve mimikler kişisel vitrinin unsurları olarak (2004, s. 27) Gofmann'ın terminolojisinde detaylandırılmıştır.

The Sims 4 Oyunu'nda bütün unsurların tamamı oyun karakteri oluşturulurken rahatlıkla değiştirilecek performans ve vitrin unsurlarının başında gelmektedir. Oyunu oynayan kişi bu dijital oyunu oynamak adına, performansı sunabilmek için istediği biçimde karakterler oluşturabilir, onu paylaşabilir, farklı bir cinsiyet ile karakter yaratabilir. İçerikle ilgili paylaşım yapılması kişinin kendisinin yerine değiş- tokuşu olarak görülmesi (Gearhart, 2009), arzu edilene yönelik ulaşmayı olanaklı hale getirmektedir. Yüz ifadesi olarak geçen jest ve mimikler oyunu oynayanın istediği doğrultuda ayarlanabilir ve duygu durumlarının sunumu olarak görülebilir. Günlük yaşamda kişiden (Goffman terminolojisiyle "oyuncu") rolünü gerçekleştirirken oyuncunun toplumsal konumuna göre hareket etmesi performansını konumuna uygun gerçekleştirmesi beklenir. Mesleki itibarını ve mevkiini toplumdaki konumuna etkisinin farkında olarak performans sergileyen oyuncu, sunumunu, yeterli olduğunu ispat etmelidir. Bu durum The Sims 4 Oyunu için düşünüldüğünde de devam etmektedir. Oyuncunun görünüşü en başta toplumsal konumunu oluşturmak ve bunu sürdürmek üzerinedir. Gerçekleştireceği rolde ve paylaşım yapacağı içerikte mesleki olarak gerçekleştirdiği alışkanlıklarının, mevkiinin ve yeterliliğinin izlerini görmek mümkündür (Goffman, 2004, s. 57).

Seyirci paylaşılan içeriklerde tutarlılık arayacaktır. Kullanıcı, gerçek hayatta sahip olmadığı özelliklerine sahipmiş gibi kendini göstermeye uğraştığında veya oyunu oynarken oyuna dâhil ettiği karakter üzerinde seyircinin onaylamayacağı durumlar oluşturduğunda, kınanır, ayıplanır veya yok sayılır. (Ancak serinin The Sims 4 Oyunu bu anlayışı biraz tersine çevirmiş gibidir. Çünkü yaratılan karakterlerin çocuk sahibi olduğu bölümlerde dünyaya gelen canlı normal bir insan şeklinde karşımıza çıkmamaktadır. Bunun yerine bir yaratık, uzaylı olarak karşımıza çıkmaktadır. Bu noktadaki ayıplama kavramı yerini farklı olanın da arzu edilmesi ve tepkilerin ölçülmesi olarak yorumlanabilir). Günlük yaşamda bireylerin, performanslarını sergilemelerinde arzu edileni gerçekleştirmediklerinde göz ardı edilecek ya da benlik sunumlarını gerçekleştiremeyeceklerini olgularla aktardığı gibi oyun oynayanların oynadıkları dijital oyunlarda da sunmayı arzu ettikleri benlikleri güçlendirecek ve inandırıcı kılacak paylaşımlarda bulunurlar. Bu performanslar gerçek hayatla uyumlu olabileceği gibi, tamamen arzu edilen benlik sunumuna göre uyarlanmış da olabilir.

Giddens, her kültürde, her toplumda, her sosyal yapıda bireysel ve sosyal yapılarda benliklerin sunumunda performansların hepsinin birbirinden farklı olduğunu ifade eder (Giddens, 1956). Bu ifadesi dijital oyunlar üzerinden yorumlandığında The Sims 4 Oyunu bireysel ve sosyal performansın ayrı ayrı 
sınırlarının silindiği birbirinin içine geçerek, mahrem ve kamusal arasında bir yapıda kendine yer bulduğu söylenebilir. Günlük yaşamda performansını gerçekleştiren kişi, kendi kendisinin izleyicisi olan veya başka bir izleyicisinin var olduğu arzusunu taşıyan oyuncu açısından dijital oyunlar kişinin kendinin izleyicisi olduğu sanal dünyanın hayallerinin gerçek kanıtı gibidir.

\section{YÖNTEM}

$\mathrm{Bu}$ çalışmada, gerçek yaşamda toplumsallaşma sürecinde inşa olan benlik sunumunun dijital oyun evreninde sanal benlik olarak nasıl yeniden sunulduğunu anlamaya yönelik bir araştırma amaçlanmaktadır. 12 bölümden oluşan bir seri olan The Sims 4 Oyunu, bütün dünyada çok yoğun ilgi gören ve gündelik hayatta benlik sunumunu desteklemesi bakımından tek örnek olduğu için, araştırmanın sonuçları iletişim ve sosyal psikoloji alanına katkı açısından ayrıca bir önem taşımaktadır. Bauman ve Raud (2018), benlik sürecini ifade etme süreci her bireyin farklı anlarda farklı şekillerde yer aldığı iki farklı evren olarak görmektedir. Öyle ki bu süreci çevrimiçi ve çevrim dışı evrenler (online ve offline) diye tanımlayarak benlik kavramının sanal ve hakikat arasındaki yapısını vurgulamaktadır. Zhao ve arkadaşlarının (2008), Goffman'ın terminolojisini referans alarak Facebook odaklı gerçekleştirdikleri çalışmalarında, bireylerin gerçek kimliklerini gizlemekten, kendilerini sakınmaktansa başkalarının kendilerini bilmelerini istedikleri hallerini kimlik olarak inşa etmeye uğraştıklarını ifade etmektedirler (Zhao vd., 2008, 1817-1818). Baumeister ve Bushman (2014) üniversite öğrencilerinin sosyal ağ vasıtasıyla benlik sunumunda Facebook'u tercih ettikleri sonucuna ulaşmışlardır. Ülkemizde ise, Çalışır (2014), "Construction, Presentation and Consumption of Individualism in Social Media" başliklı çalışmasında sosyal medyanın benliğin inşası, benlik sunumu ve tüketiminde bireyin toplumsallaşma sürecinde etkili olduğunu ifade etmektedir. Bireyin fiziksel ihtiyaçlarını karşılamak için yaşama anlayışı, bireyin sosyal platformlarda var olmak için yaşama anlayışına doğru evrildiği bir sürece dikkat çekmektedir. Özdemir'in (2015) Goffman'ı referans alarak yaptığı "Sosyal Medyada Kimlik İnşasında Yeni Akım: Özçekim Kullanımı" başlıklı çalışmasında sosyal ağlarda benlik sunumunu özçekim fotoğrafları üzerinden değerlendirmiştir. Çalışmada, bireylerin özçekimi yaşamın merkezine aldığı, sosyal hayata karışmak, dikkatleri üzerine toplamak ve diğerlerinden farklılaşmak amacı güttükleri sonucuna ulaşmıştır (Özdemir, 2015: 128). Böylelikle benlik ve benlik sunumu hızla üretilen, tüketilen, değişime uğratılan bir meta olarak konumlanmıştır. Algül (2018) "Sosyal Ă̆ Kullanıcılarının "Abartılı Paylaşım", "Benlik Sunumu" ve Mahremiyet Tüketimleri" başlıklı çalıșmasında gelișen olanaklarla yaşam pratiklerindeki değişimleri gözlemlemenin mümkün olabileceğini bunun da en büyük göstergelerinden birinin sosyal ağlar olduğunun söylenmesinin yanlış olmayacağını ifade etmiştir. Çakmak (2018) "Online Benlik Sunumu ve Narsizm Arasındaki İlişki: Üniversite Öğrencileri Üzerinde Bir Araştırma" başlıklı çalışmasında ise online ortamlarda benlik sunumu davranışının ne olduğu ve üniversite öğrencilerinin görüşleri doğrultusunda benlik ve sanal ortama benlik kavramına vurgu yaptığ1 görülmüştür. Özdemir ve Yıldırım (2019) ise "Dijitalleşen İletişim Ortamlarında Kimlik İnşası ve Benlik Sunumu: İletişim Fakültesi Öğrencileri Üzerine Bir Araştırma" başlıklı çalışmada, benlik oluşumunun durağan bir evre olmadığı ve sosyal medya gibi dijital iletişim platformlarında, sınır kavramı olmadan etkileșim olanağı sağlayan yapılanmalar bireylerin benlik ve kimlik inşasında etkili olurken benlik sunumu için birer ortam haline dönüştügünü vurgulamaktadır. Bütün bu bilgiler 1şığında benlik ve benlik sunumuna yönelik güncel araştırmaların varlığı konunun önemini ortaya koymaktadır. Öyle ki yapılan bütün literatür taramalarında benlik sunumu ve dijital oyunlar üzerinde bir çalışmaya rastlanmamıştır. $\mathrm{Bu}$ oyun özelinde benzer bir çalışmanın yapılmamış olması nedeniyle iletişim alanında özgün bir çalışma olması amaçlanmaktadır. İncelemeden elde edilen sonuçları yorumlamak amacıyla betimsel bir araştırma yapılmıştır. Bu doğrultuda The Sims 4 dijitial oyunu üzerine, Erving Goffman'ın Benlik Sunumu teorisine dayalı literatürden elde edilen modellemeye dayanarak, nitel içerik analizi yapılmışıtır. İçerik Analizi Yöntemi, bilgi değeri taşıyan her türlü verinin araştırma amacı doğrultusunda taranması, sınıflandırılması, özetlenmesi, bulguların araştırmanın amaçları doğrultusunda çözümlenmesi ve yorumlanması işlemlerini kapsayan bir yöntem olarak araştırmanın amacı için uygun görülmüşsür (Yurtseven, Erkul ve Morkoç, 2013, s. 73; Neuman, 2008).

The Sims, Will Wright'ın bir yangın sırasında bütün mal varlığını ve evinin kaybını yaşadığı deneyiminden doğmuştur. Yaşadığı zorlu durum sonucunda yaşamın bir tür simülasyonunu oluşturma düşüncesiyle, hayalini oyunlaştırarak gerçekleştirmiş̧ir. Bu dijital oyun, sanal bir şehir yaşamı ve bu şehrin sakinlerinin gündelik yaşam deneyimleri oluşturma teması üzerine kurulmuştur. İlki 2014 yılında, 
Sim City adıyla Electronic Arts tarafindan kurulmuş olan oyun, 2017 y1lında serinin 4. sünü piyasaya sürmüştür.

The Sims Oyun formatında, oyunu oynayan herkesin kendi hayatını kurgulayabileceği bir içerik vardır. $\mathrm{Bu}$ durum birçok farklı karakteri birç̧ok farklı şekilde gerçekleştirme ve oyuna dâhil etme şeklinde görülür. Karakterlerin hedef kitleleri farklıdır ve bu karakterlerin belirli kimlikleri ve yaşam biçimlerini temsil ettikleri görülür. Goffman'ın alan tanımlamasındaki gibi, Sim City evrenindeki oyun kurgusu, mahrem alandan kamusala alana kadar benlik sunumun inşa olduğu bütün mekanlarda geçmektedir. Oyun, gerçek insanların sanal benlikleriyle kendilerini var ederek sosyalleştikleri, seçimleri doğrultusunda farklı senaryoların türetildiği ve etkileşimsiz kurgusuyla tekrar tekrar var olabildikleri sanal bir toplumsallaşma mekanı sunmaktadır.

The Sims Oyunu ayrı ayrı parçalar içermektedir. Bu oyunda yer alan parçalar bir sonraki parçayla kurguyla bağlıdır. Açık uçlu anlatımlara sahip olan oyunda, yaşanan çatışmaların yoğun duygulara dayandığ 1 görülür. Olaylardan çok meydana gelen olayların sebep olduğu durumlar üzerine bir anlam yüklemenin önemli olduğu gözlenir. Olaylar karşısında karakterlerin sık sık sorun yaşamaları, maddimanevi süreçte her insanın hayatında yaşadığı iniş çıkışları görüp, buna karşı direnme ya da vazgeçmeleri, oyunu oynayanlarda oyunun gerçeklik duygusunu ve algısını arttırır. Böylece oyunu oynayanlar The Sims Oyunu'ndaki anlatının içine çekilir ve bu sırada oyuncular ile karakterler arasında özdeşleşme sağlanmış olur. Anlatının içinde yer alan oyunu oynayanlar artık Sims'lerin gündelik hayatlarına, aile ortamlarına, çatışmalarına, kültürlerine en önemli tanıklarıdır. Bu ortamda hem kendi oluşturdukları karakterlerle bir kimlik inşa etmekte, hem de sosyalleşme sürecinde benliklerinin sunumunu gerçekleştirmektedirler. Ancak oyuncu/katılımcılar farkında olmadan moda tercihleri, yeme içme kültürleri, boş zaman aktivitesi, evcil hayvan bakımı gibi modern şehirli birey aktivitesinin simülasyon senaryoları ile bilinçaltına toplumsal davranış kalıplarıyla ilgili rol modeli olacak mesajlar vermektedir. The Sims bir yaşam simülasyon oyunudur.

\section{BULGULAR}

$\mathrm{Bu}$ kategoriler, daha önce yapılmış benzer çalışmalar incelenerek ve araştırmanın evrenini oluşturan dijital oyunun bölümleri izlenerek yapılan ön araştırma sonucunda oluş̧urulmuştur. Kategorilerle ilgili ayrıntılar aşağıdaki şekildedir (Goffman, 2004, s. 28).

Tablo 1. The Sims 4 Künyesi

\begin{tabular}{|l|l|l|}
\hline \multirow{2}{*}{} & Oyunlar & \multicolumn{1}{c|}{ Tanım-Oyun Detaylarl- Özellikleri } \\
\cline { 2 - 3 } \multicolumn{4}{c|}{} & Yayımcılar & Electronic Arts, Maxis \\
\cline { 2 - 3 } & Yapımcılar & Electronic Arts, Maxis \\
\cline { 2 - 3 } & Seri & The Sims \\
\cline { 2 - 3 } & Tarih & 2014 \\
\cline { 2 - 3 } & Tür & Yaşam Simülasyonu \\
\cline { 2 - 3 } & Cinsiyet & $\begin{array}{l}\text { Şehir yaratma söz konusu olduğundan her iki cinsiyete yer verilirken } \\
\text { kadın ve erkek belirgin rollerle birbirinden ayrılmaktadır }\end{array}$ \\
\cline { 2 - 3 } & $\begin{array}{l}\text { Kullanılan } \\
\text { araçlar }\end{array}$ & $\begin{array}{l}\text { Yeni yaşam alanı yaratmakta ve insanın ihtiyaç duyabileceği bütün } \\
\text { araçlar tuşlarla sunulmaktadır. }\end{array}$ \\
\cline { 2 - 3 } & $\begin{array}{l}\text { Teknolojik } \\
\text { araçlar }\end{array}$ & $\begin{array}{l}\text { Dijital platforma gerçek hayat inşası olması ve insanın gündelik hayatta } \\
\text { ihtiyaç duyabileceği, benlik sunumunda kullanabileceği bütün } \\
\text { teknolojik araçlar yoğunluktadır. }\end{array}$ \\
\hline
\end{tabular}

Oyun; Şehir Yaşamı, Toplanma, İşe Başlama, Evcil Hayvanlar, Masaj Günü, Vampirler, Akşam Yemekleri Törenleri, Ürperti, Dinlenme, Bowling Buluşmaları, Ebeveynlik, Emekleme Dönemi Geçiren Bebeklik, Çocuk Odası, Mevsimler, Videolu Sohbet Ortamları, Sihirli Şeyler, Arka Bahçe Orman Macerası isimli bölümlerden oluşmaktadır.

The Sims 4 Oyunu'ndaki içerik, Goffman'ın terminolojisi referans alınarak; Aktör, Performans, Sahne, Seyirci, Rol ve Vitrin kategorilerine göre Benlik Sunumu açısından aşağıda değerlendirilmiştir: 
Tablo 2. Erving Goffman'in Benlik Sunumu Kategorileri

\begin{tabular}{|c|c|c|c|}
\hline \multirow{2}{*}{$\begin{array}{l}\text { Kategorilerin } \\
\text { bölümlere } \\
\text { göre } \\
\text { incelenmesi }\end{array}$} & \multicolumn{3}{|c|}{ THE SIMS 4} \\
\hline & $\begin{array}{ll}\text { 1. } & \text { Bölüm } \\
\text { 2. } & \text { Bölümm } \\
\text { 3. } & \text { Bölüm } \\
\text { 4. } & \text { Bölüm } \\
\end{array}$ & \begin{tabular}{|cl} 
5. & Bölüm \\
6. & Bölüm \\
7. & Bölüm \\
8. & Bölüm \\
\end{tabular} & $\begin{array}{ll}\text { 9. } & \text { Bölüm } \\
\text { 10. } & \text { Bölüm } \\
\text { 11. } \text { Bölüm } \\
\text { 12. Bölüm } \\
\end{array}$ \\
\hline Performans & $\begin{array}{c}\text { Yeni yaşam alanı } \\
\text { yaratmak ve sosyal } \\
\text { ortama dahil olmak için } \\
\text { sergilenen davranışlar }\end{array}$ & $\begin{array}{c}\text { Simlerin buluştuğu, artık } \\
\text { sosyal insan olma } \\
\text { bölümlerinin eklendiği } \\
\text { mekan anlayış1 yaratmak } \\
\text { için sergiledikleri } \\
\text { davranışlar } \\
\end{array}$ & $\begin{array}{c}\text { Simler'in yaşadığı } \operatorname{Sim} \\
\text { şehrinin dünyaya açılan } \\
\text { kapısı ve o kapının } \\
\text { moderniteye ayak } \\
\text { uydurabilen bir yaşam alanı } \\
\text { olması. } \\
\end{array}$ \\
\hline Aktör & $\begin{array}{l}\text { Sim şehrinde görüntüye } \\
\text { dahil olan birçok kostüm } \\
\text { ve objeleri kullanan } \\
\text { kişiler ve özellikleri ( } \\
\text { Yaş, cinsiyet, ırksal } \\
\text { özellikler, yüz ifadeleri, } \\
\text { vücut yapıları }\end{array}$ & $\begin{array}{c}\text { Oyunun yoğunlukla } \\
\text { vurgu yaptığı sanal } \\
\text { insanı"”gerçek } \\
\text { hayatlara" özgü değerler } \\
\text { ve objelere sahip olma } \\
\text { arzusu yaratma } \\
\text { eğiliminde bulunan } \\
\text { bireyler. }\end{array}$ & $\begin{array}{l}\text { Sim şehrinin dokuların } \\
\text { yoğun olduğu yerlerdeki } \\
\text { hayat biçimine, şahitlik } \\
\text { etme arzusu doğurmaya } \\
\text { yönelik mesajları oluşturan } \\
\text { bireyler }\end{array}$ \\
\hline Sahne & $\begin{array}{c}\text { Simler'in } \\
\text { performanslarını } \\
\text { sergiledikleri } \\
\text { sosyalleştikleri bütün } \\
\text { alanlar. } \\
\end{array}$ & $\begin{array}{l}\text { Simler'in performans } \\
\text { sergiledikleri kamusal ve } \\
\text { özel alanları kapsar. }\end{array}$ & $\begin{array}{c}\text { Simler'in benliklerini } \\
\text { sergilemek için kullandıkları } \\
\text { alanlar (Kafe, kütüphane, } \\
\text { bar, v.b. alanlar) }\end{array}$ \\
\hline $\begin{array}{l}\text { Seyirciler/ } \\
\text { Gözlemciler }\end{array}$ & $\begin{array}{l}\text { Perfomans1 sergileyen } \\
\text { Simler' in katılım } \\
\text { gösterdiği alanlarda } \\
\text { performansın dışında } \\
\text { kalanlar. }\end{array}$ & $\begin{array}{c}\text { Simler'in etkileşim } \\
\text { kurmak için dahil } \\
\text { oldukları alanlarda yer } \\
\text { alan ve “ötekiler" olarak } \\
\text { ifade edilenler. }\end{array}$ & $\begin{array}{c}\text { Simler'in davranış } \\
\text { kalıplarını ve benlik } \\
\text { sunumlarını takip edenler. }\end{array}$ \\
\hline Rol/ Rutin & $\begin{array}{l}\text { Simler'in günlük } \\
\text { hayatlarında } \\
\text { sergiledikleri bütün } \\
\text { eylem ve davranışlar. }\end{array}$ & $\begin{array}{l}\text { Simler' in kendilerini } \\
\text { gerçekleştirirken sahip } \\
\text { oldukları konumları ve } \\
\text { konumlarına uygun } \\
\text { davranma eğilimleri } \\
\end{array}$ & $\begin{array}{l}\text { Simler'in inşa edilen alanda } \\
\text { (meslek, eğitim, iş, kariyer } \\
\text { ve statü durumlarına) uygun } \\
\text { davranma halleridir. }\end{array}$ \\
\hline
\end{tabular}

Aktör: Sanal gerçekliğin sonucunda karakterlerin fiziksel görünümleri tamamen oyunu oynayanın elindedir. Fiziksel özellikler tamamen ayarlanabilir. İsteğe göre genç ve güzel, isteğe göre yaşlı ve şişman bir özellik seçilebilir. Oyunda insan ve insana dair bütün fiziki karakteristik bütün özellikler seçilebilmektedir. İnsan yüzündeki her detay ayarlanabilmektedir. Oyunda oyunu oynayan karakterlerin beden dili, jest ve mimiklerine kadar müdahale hakkı vardır. Örneğin, karakterin yürüyüş ve duruşuna kadar seçim hakkı verilmektedir. Oyunda ten renkleri de seçime sunulmaktadır. $\mathrm{Bu}$ özellikler doğrultusunda oluşturan Sanal Karakterin sanal kimliğine kadar kaydı oluş̧uruluyor. Oyun başlangıcında 20.000 sims parası verilmektedir. Oyuncu / aktör farklı farklı karakterler yaratabiliyor. Yaratılan her karakter için 2.000 sims parası veriliyor.

Rol / Rutin ve Statü: Kişisel olarak oluşturulan fiziksel özelliklerin yanında sosyo- ekonomik statüler de oyunu oynayanın istediği yönde değiştirilebilir. Çekici, gizemli, utangaç, etkileyici görünüm seçenekleriyle bedensel görünümleri ve duruşları belirlenebiliyor. Örneğin Simler'in yürüyüşünden duygu- durumları hakkında yorum yapmaya olanak tanımaktadır. Öyle ki mutsuz olan Sim kamburu çıkmış, başı yere eğik, eylemlerine daha zor odaklanabilen ve ağır yürüyüş sergileyerek kendisi hakkında bilgi vermektedir. Oyuncunun tasarısına bırakılan karakter oyunun kurgusunda sunulan seçeneklerle 
sınırlandırılmış farklı seçenekler için farklı senaryolar gelişiyor. Çok fazla seçenek olsa da özünde tamamen bir özgürlük söz konusu değildir. Örneğin karakterlerin doğum günlerini kutlamayınca moralleri bozulmaktadır. Ve bu da bir yapay zeka aracılığıyla gerçek yaşamdaki toplumsallaşma süreçlerinin sanal bir ortamda karakterleri insanlaştırma simüle edildiğinin göstergesi olarak okunabilir.

Sim'lerin ihtiyaçlarını gidermek için çalışabilecekleri işleri vardır. Sim'lerin kariyerlerinde de olağan hayat akışı vardır. Kariyerde yükselmek ve gelişmek için Simler yeniliklere uyum sağlamaktadır. Teknolojinin getirisi ile yeni meslekler ve meslek tanımları Simler'de de görülebilmektedir. Sim sosyal medya uzmanlığı gibi bir alana da yönelebilmektedir. Farklı meslek dallarının seçimini yaptığında farklı senaryolarla karşılaşılmaktadır. İşe geç kalmalarda veya okula devamsızlık yaptıklarında moral bilgisinde motivasyondan kaynaklı olumsuzluklar olmaktadır.

İdeal Benlik: Kişi gerçekte olduğu gibi bir oyun karakteri oluşturabileceği gibi, olmayı arzu ettiği karakteri de oyunda oluşturabilir. Bu sayede "umut edilen kimlikler" üreterek, umut edilen benlik sunumunu gerçekleştirebilir. Oyunda bir insanın yaşamında sahip olduğu bütün süreçler vardır. 3 gün süreyle yaşanan bir hamilelik vardır. Karakterlerin doğum, büyüme, ölüm süreçleri canlandırılmaktadır. İdealize bir dünyanın sunumunu görebilmekteyiz.

Sahne: Oyuna başlarken oluşturulan karakterlerde yaşam sosyal ortamda (mahalle, kütüphane, kafe, cadde, toplantı ortamlarında ve davetlerde)devam ettirilir. Modern ve ideal bir şehir yaşamında, sosyal canlılığın, toplumsallaşmanın, karşılıklı iletişimde bulunmanın ve benlikleri sunmanın alanı olarak parklar, yürüyüş parkurları, bahçeler, kafeler, barlar bu oyunda göze çarpmaktadır. En büyük ödül hayat iksiridir. Oyundaki bölümün içeriğine göre farklı etaplarda bu ödül veriliyor, böylece karakter ölmeden oyuna devam etme şansı elde ediyor. Diğer yapay zekâların yönettiği Sim'lerin bulunduğu 2 tane mahalleden 1 ev veya arsa satın alıp ev yapılması istenir. Tercihe göre sosyal ortama katılım sağlanır. Mahallede oyun zamanı akmaya başladıktan sonra evin önünden geçen her Sim’le(yapay zekâ) iletişime geçebilmek mümkündür.

Performans: Oyunda Simler'in komşuluk ve arkadaşlık kurmasına olanak verilir. Karakter oluşturma, ev sahibi olma, kariyer ve aile ilişkileri de oyunda ayrıntılı olarak sunulmaktadır. Her hamlede karakterlerin duyguları, düşünceleri ve motivasyonları hakkında bilgi içermektedir. Beraberinde karakterlerin burçları, beğendikleri yiyecekleri, beğenecekleri müziği, favori gördükleri renkleri bile oyunu oynayanın kendisi belirleyebilmektedir. Doğum izni, nişanlanma, evlenme gibi ritüellerle birlikte flört, romantik ilişkiler, aldatma ve boşanma da var. Simler' in de özel günleri var ve bu özel günlerine ayrıca dikkat ettikleri görülmektedir. Düğün, toplantı, konser, doğum günü gibi günlere önem vermekteler ve bu özel günlerin hatırlanmaması Simler' i çok üzmektedir.

Yaşadıkları duygu durumunu ifade edecekleri duygu halleri oyunu ayrıca gerçekçi kılmaktadır. Simler'in de kendilerine göre korkuları, istekleri ve ihtiyaçları vardır. Onların da onanma, sevgi görme ve aidiyete yönelik istekleri olduğunu göstermektedir. Oyunda yalan söylemek eklentisiyle, Sim'lerle iletişimdeyken kariyerleri hakkında yalan söyleyerek kendini övebilmektedir. Bugün gerçek hayattaki insanların da iletişim şsekline ve kariyer sürecine bir ayna tutmaktadır. Oyunda emeklilik kavramı da yer almakta ve bir Sim doğal yollardan ölebilmektedir. Örneğin bir aile bireyi öldüğünde Simler depresyona girebilmekte, diğerlerinden kaçmak için yorgan altına girip ağlayabilmekte ve üzüntüden ölebilmektedir.

Simslerin "Sanal Karakter Oluşturma Kategorileri” aşağıdaki tabloda oyundaki sırasında gösterilmektedir. 
Tablo 3. Sanal Karakter Oluşturma Kategorileri

\begin{tabular}{|c|c|c|}
\hline \multirow{17}{*}{ 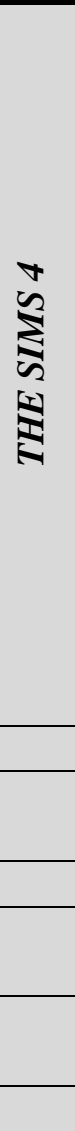 } & $\begin{array}{l}\text { Oyundaki } \\
\text { Kategoriler }\end{array}$ & Karakter Özellikleri \\
\hline & $\begin{array}{l}\text { Karakter } \\
\text { Yaratma }\end{array}$ & Karakter isimlendirilir ve soyad verilir. \\
\hline & Cinsiyet & $\begin{array}{l}\text { Kadın-erkek ve de yaşlllık seçilebiliyor. (çocuk-genç-genç yetişkin- } \\
\text { yetişkin-yaşll). Oyunda geçen her } 20 \text { günde evreler ilerler. }\end{array}$ \\
\hline & $\begin{array}{l}\text { Yürüyüş } \\
\text { seçenekleri }\end{array}$ & Normal, neşeli, kibirli, havalı, kadınsi, sert, aptalca, halsiz, yaşam dolu \\
\hline & Ses tonu & $\begin{array}{l}\text { Ince-kalınlık ayarı yapılabilir. Kadın karakterde: melodik, şarkıcı, tatll. } \\
\text { Erkek karakterde: samimi, temiz, atılgan }\end{array}$ \\
\hline & Aile & Seçilebilen bir özellik şeklindedir. Başarıll, soylu, mutlu büyük bir aile \\
\hline & Bilge & Zeka küpü, bilgisayar dehası, kitap kurdu. \\
\hline & Doğal & Müze müdürü, balıkçı. \\
\hline & $A s ̧ k$ & Seri romantik, ruh ikizi. \\
\hline & Popüler & Parti delisi, şakacı \\
\hline & Yaratici & Ressam, şair ruhlu, müzik dehası \\
\hline & Yemek & İçki ustası(yaratıcı kokteyller), usta aşçı \\
\hline & $\begin{array}{l}\text { Duygusal } \\
\text { özellikler }\end{array}$ & Aktiflik, aptallık, dahi, kendinden emin, yaratıcı, hüzünlü, kızgın, neşeli \\
\hline & Hobiler & Kitap kurdu, çalışkanlık, sanat aşı̆̆l, mükemmelliyetçi, yemek yemek \\
\hline & $\begin{array}{l}\text { Sosyal } \\
\text { ozzellikler }\end{array}$ & Dost, kötü, yardımsever, huysuz, uyumlu, çekimser, aile odaklı \\
\hline & $\begin{array}{l}\text { Fiziksel } \\
\text { özellikler }\end{array}$ & $\begin{array}{l}\text { Zaylf, şişman, kasll, normal ( detaylı olarak bütün fiziksel özellikler } \\
\text { verilebilmekte) }\end{array}$ \\
\hline & Intiyaçlar & Maslow'un ihtiyaçlar hiyerarşisindeki bütün ihtiyaçlar mevcut. \\
\hline
\end{tabular}

İletişim Kurma Şekli: Derin konuşma (muhabbet), gün hakkında konuşma, şakalaşma, dedikodu olarak görülmektedir. Sim'lerle iletişim, bulunulan mekâna, eşya ve nesnelere göre samimiyet yönünden farklı şekillerde oyuncunun karşısına çıkmaktadır. İkili ilişkileri görebilmek, durumun ne düzeyde olduğunu sohbet ederken görüntülenmektedir. Kalabalık sohbet grupları oluşturulup, herkes birbirinin arkadaş çevresiyle kaynaşabilmektedir. Bir kere "selam" denilen Sim diğer Sim'in evine rahatlikla gelebilmektedir ve bu komşuluk kültürünü işaret etmektedir. Sosyalleşmek için gidilen mekanlarda hiçbir şekilde ayakta yemek yenilmemektedir. Fast food kültürüne verilen savaş mesaj olarak verilmektedir.

Seri halindeki oyunda her bir bölüm diğerinin devamı ve teknolojinin getirisiyle yeni eklemelerle de dikkat çekmektedir. Öyle ki oyunda aile hayatına ve aile içi iletişime kadar birçok detay göze çarpmaktadır. Simler'in aile hayatında olumsuzluk varsa ve ev halkında genel bir mutsuzluk varsa onların kalbini kazanmak için bozuk eşyaları tadilata sokmak, eşyaları tamir ettirerek, evde çeşitli tadilatlar yaparak mutsuzluğu dağıtmak mümkün olmaktadır $\mathrm{Bu}$ da aile olabilmek için aile adına bir şeyler yapmanın gerekliliği olarak yorumlanabilir. Gün içinde sinirlenen Simler' in moral bozukluğu dolaylı yoldan davranışlarına da yansımaktadır. Örneğin buzdolabının kapağını açıp kapatırken sertçe vurmaları bu duygu- durumlarını görünür kılmaktadır.

Simler'in bebekleri de ayrı bir değerlendirme noktasıdır. Bir bebek ne kadar yüksek sesle ağlarsa ağlasın anne ya da baba mühim bir işle uğraşıyorsa bebeklerin ağlamalarını umursamazlar. Yalnız bu davranış sıklıkla tekrarlanırsa Sosyal Güvenlik Hizmetleri bebeği ailenin elinden almaktadır. Burada da subliminal olarak günümüz modern insanına vurgu ve sorumlulukların yerine getirilmediği takdirde otoritenin devreye gireceği mesajı verilmektedir.

Modern insana vurgunun yoğun bir şekilde verildiği bir diğer detay da Simler umursamaz değil, yoğun çalışmaktalar mesajıdır. O kadar çok sorumluluk ve görevleri vardır ki bu da onları kısmen medeni ilgisiz hale getirmektedir diye yorumlanabilir. Yine çağın tartıştı̆̆ 1 çoklu yetenekleri Simler'de de görmek mümkündür. Sürekli bir şeylerle uğraşan Simler bu yeteneklerini gündelik hayatlarına da 
taşırlar. Öyle ki televizyon karşısında yemek yerken hem orayı takip etmek hem de beslenme ihtiyacını karşılayabilmektedir. Ya da kitap okurken, müzik dinleyebildikleri, bir yandan telefonla konuşurken, bir başka işlerini halletmeye çalıştıkları görülmektedir.

Telefonla fotoğraf çekilmek ve öz çekim (selfie) özellikleri ayrıca dikkat çekmektedir. Daha önceki bölümlerde gazeteci çocuk tarafindan gazete getirilirdi. Gazeteden iş ilanına bakıp, iş seçilirdi. Oyunda konvansiyonel medya yerini yeni medyaya bırakmakta ve iş başvurusu da bunda doğrudan etkilenmektedir. Gündelik yaşamdaki gelişmelerin yansımaları oyundaki tasarılarda görülmektedir.

\section{SONUÇ}

Teknolojide meydana gelen değişmeler birç̧ok gelişimi de beraberinde getirmiştir. Hız ve ulaşılabilirlik teknoloji ile birçok şeye etki etmiştir. Öyle ki insanlar günlük yaşamını sürdürmek için de teknolojiyi bir araç olarak kullanmanın ötesine geçmiştir. Teknoloji yaşamlarının her saniyesini ve her yerini etkileyerek bir yaşam pratiği olarak kabul edilmiştir. Teknolojinin çevre ile iletişim sağlamada, yaşamı devam ettirmede, yaşamlarda değişikliğe gitmede ve gerçeği sanalla ikame etmede bir araç olarak görülmektedir. Kişinin, yalnızca gerçeği paylaşmakla kalmamakta, arzu edilen kişi olmak adına da dolaylı yollarla etkileșimini sürdürmek için teknolojiyle içli dıșlı olduğu iddiası hâkimdir. Tarım Toplumu'ndan Sanayi Toplumu'na uzanan süreçte teknoloji ile yaşanan ve çağa ismini veren Bilişim Toplumu dijital olarak da bir değişim yaşatmıştır. İletişim ve iletişim teknolojilerinde yaşanan değişimler bireyleri, bireyler arasındaki iletişimi ve toplumsal iletişim anlayışını da değişime uğratmış̧ır. Bireyin var olmak, ihtiyaçlarını karşılamak için kurduğu iletişimden teknolojik uzantıların işaret ettiği bir iletişim anlayışına eğilim olmuştur. Bireyi diğerlerinden ayıran, bireyin kendini ifade etme biçimi ve bütünün toplamı diye ifade ettiğimiz benlik kavramı teknolojik uzamda da yeni bir yöne evrilmiştir. Kendini ifade etmek isteyen, anlaş1lır kılmak isteyen birey, diğerleriyle etkileşime geçerek iletişim kurma yoluna gitmiştir. Benlik sürecini oluştururken kendisini "ben” yapan bütün fiziksel ve duygusal özelliklerini geleneksel bir anlayış ile diğerlerinin arasına karışarak "toplumsallaşarak" gerçekleştirmekteydi. Bir davette, bir toplantıda, bir yemekte, kamusal alanda veya bireysel alanlarda davranışlarını görünür kılarak diğerlerini etkileme çabasındaydı. Nasıl algılanmak istiyorsa o şekilde eylemlerde bulunarak benlik sunumunu gerçekleştirmekteydi. Ancak iletişim teknolojilerinde yaşanan değişim ve gelişmeler bu süreçlerin boyutunu da etkilemiştir. Eskiden karşılaşma alanı olan "toplumsal hayat ve mekânlar" yerini internet uzantılı alanlara bırakmıştır. Birey; benlik inşası, kimlik ve benlik sunumu için dışarı çıkmadan dışarıda olma imkânı bulmuştur. İnternet uzantılı yeni iletişim teknolojileri ile sanal ortamlarda var olmaya başlamıştır. İnternet uzantılı yeni iletişim teknolojileri ile sanal ortamlarda var olmaya başlamıştır. Gelenekselden yeniye uzanan bir süreç olarak tanımlayacağımız ve dijital evrim olarak göreceğimiz bu yaklaşımla bireyler sanal ortamların gerçek bireyleri, sanal bireylerin gerçek ortamları gibi bir yanılsama evreninden var olma çabası ile benlik oluşturma, benlik sunumu ve kimlik kavramlarını daha da önemli kılmıştır. Öyle ki dijital evrende oluşturulan sanal süreçlerin bireye, bireyin var olmasına, benlik inşasına ve kimlik oluşumunda etkisi göz ardı edilemez boyuttadır. Bütün bu bilgiler 1şı̆̆ında dijital oyunlarda da benlik inşası, benlik sunumu ve kimlik oluşturma gibi süreçleri gözlemlemek mümkün olmaktadır. Bu dönüşümle yeni iletişim teknolojileri sayesinde bireyler de benliklerini ve imajlarını sanal ortamda kurgulayarak arzu ettikleri biçimde sunabilmektedirler. "The Sims 4 Oyunu", çevre ile iletişimde kanal görevi gören, hatta sanal âlemle gerçek âlemin birbirinin yerine değiş- tokuş edildiği popüler bir dijital oyun olarak ön plana çıkmaktadır. Hem bir oyun alanı hem de bir oyun aracı olarak The Sims 4 Oyunu, yaratılan karakterlerin kurucu/oyuncu sayesinde bir araya gelip etkileşime geçecekleri ve iletişim kurabilecekleri ortamlar sunmaktadır.

Sanal ortamda şimdiki zaman ifadesinin habitusu olarak karşıllk bulan ve üçüncü bir ortam şeklinde görülebilecek bu ortam, kullanıcılarına verdiği ortam yaratma, içerik oluşturma ve paylaşma, gerçek yaşamda sahip olduğu veya sahip olmayı arzu ettiği her şeyle ilişkili bağlarını sürdürme imkânıyla birçok dijital oyundan ayrılmaktadır. Oyun karakteri için bir kimlik oluşturarak profil açmayı zorunlu kılan The Sims 4, oyunu oynayanların gerçek yaşamlarındaki sosyal sermayelerini bir platforma taşıdıkları ölçüde yaşamlarının bir parçası, sıcak ve soğuk ilişkilerini kurguladıkları bir yapı, benlik sunumu inşa ettikleri sanal bir ortam haline gelmiştir.

Bu sebeplerle Erving Goffman'ın “Gündelik Hayatta Benlik Sunumu” kavramı dijital oyunlar üzerinde kavramsal çerçeveye oturtularak bir yaşam simülasyon oyunu olan The Sims 4 Oyunu özelinde 
incelenmiştir. Bu örnek, internetin bir uzantısı olarak hayatlara dâhil olan dijital oyunların sadece eğlenmek, rahatlamak, boş zaman geçirmek, motive olmak ya da birçok problemden kaçmak için oynanmasının ötesine geçtiğin önemli göstergesidir. Dijital çağın gerçek insanlarının, dijital dünyalarında alternatif bir yaşam tasarlayarak dijital kültürlerini yaşadıkları veya kurguladıkları kimlikleriyle benliklerini sundukları bir platform haline evrildiğini söylemek yanlış olmayacaktır. Ancak bu benliklerin sunumu da sonsuz seçeneğe sahip değildir, sadece gerçeğin izdüşümü alternatifler sunmaktadır. Gündelik hayatların izdüşümüne denk gelen dijital oyunlar, ideal benlik sunumu ve performansların sergilendiği bir yapı olarak kişilerarası iletişim ve sosyal psikoloji alanı açısından üzerine düşünmeye değer veriler sunmaktadır.

\section{KAYNAKÇA}

Algül, A. (2018), Sosyal ağ kullanıcılarının "abartılı paylaşım", "benlik sunumu" ve mahremiyet tüketimleri. Marmara Üniversitesi Öneri Dergisi, 13(49), 21-44.

Araz, A. (2005). Kişilerarası ilişkilerde benlik sunumu. İstanbul: Varlık Yayınları.

Alexander, D. M. (2014). The presentation of self in massively multiplayer online games. Yayınlanmamış doktora tezi, Nottingham Trent Üniversitesi , UK.

Bacanlı, H. (1990). Kendini ayarlama becerisinin çeşitli değişkenlerle ilişsisi. Yayınlanmamış doktora tezi, A.Ü. Sosyal Bilimler Enstitüsü, Ankara.

Bauman, Z. ve Raud, R. (2018). Benlik pratikleri. İstanbul: Ayrıntı Yayınları.

Baumeister, R. F. ve Bushman, B. J. (2014). Social psychology and human nature. Canada: Wadsworth Cengage Learning.

Binark, M. ve Bayraktutan-Sütcü, G. (2008). Kültür endüstrisi ürünü olarak dijital oyun. İstanbul: Kalkedon.

Binark, M. (2007). Yeni medya çalışmalarında yeni sorular ve yöntem sorunu. Yeni medya çalışmaları. Ankara: Dipnot Yayınları.

Binark, M., Sütçü, G. B. ve Fidaner, I. B. (2009). Dijital oyun rehberi oyun tasarımı türler ve oyuncu. İstanbul: Kaledon Yayınc1lık.

Çakmak, V., (2018). Online benlik sunumu ve narsisizm arasındaki ilişki: üniversite öğrencileri üzerinde bir araştırma, AJIT-e: Online Academic Journal of Information Technology, 9(30), 137-152.

Çalışır, G., (2014). Construction, presentation and consumption of indlvıdualism in social media. Journal of Media Critiques (JMC).

Erbay, E., ve Vural, A.R. (2010). İlköğretim 4. ve 5. sınıf öğrencilerinin bilgisayar oyun bağımlılığını etkileyen faktörler. İzmir: Ege Ĕgitim Dergisi, 11(1), 39-58

Gearhart, S. (2009). You are what you post: using social network profiles to express identity. Yayımlanmamış yüksek lisans tezi, San Antonio, M.A. University of Texas, USA.

Giddens, A. (2010). Modernite ve bireysel kimlik, geç modern çağda benlik ve toplum. Tatlican, Ü. (Çev.). İstanbul: Say Yayınları.

Goffman, E. (2004). Günlük yaşamda benliğin sunumu. Cezar, B. (Çev). İstanbul: Metis Yayınları. 
Goffman, E. (2017). Kamusal alanlarda ilişkiler toplu yaşamın mikro incelemeleri. İstanbul: Heretik yayınları.

Güçdemir, Y. (2010). Sanal ortamda iletişim, bir halkla ilişkiler perspektifi. İstanbul: Derin Yayınları.

Gülsoy, S. (2015). Video oyunları sosyolojisi: bir kuramsallaştırma denemesi. Uluslararası oyun ve Oyuncak Kongresi, Erzurum.

Horzum, M.B. (2011). İlköğretim öğrencilerinin bilgisayar oyunu bağımlılık düzeylerinin çeşitli değişkenlere göre incelenmesi. Eğitim ve Bilim, 36, 57-68.

Henricks, T. S. (2010). Caillois's man, play, and games an appreciation and evaluation. American Journal of Play, 3(2), 157-185.

Huizinga, J. (2006). Homo ludens, oyunun toplumsal işlevi üzerine bir deneme. Mehmet Ali Kılıçbay (Çev.). İstanbul: Ayrıntı Yayınları.

Kağıtçıbaşı, Ç. (2004). Yeni insan ve insanlar. İstanbul: Evrim Yayınları

Karaoğlu, B. (2015). Gündelik hayatta benlik sunumun sosyal paylaşım ağı facebook üzerinden incelenmesi. Yayımlanmamış yüksek lisans tezi, Ankara Üniversitesi Sosyal Bilimler Enstitüsü, Ankara.

Leary, M. R. (1996). Self-presentation, impression management and interpersonel behaviour. Oxford: Weatview Pres.

Lefebre, H. (2007). Modern dünyada gündelik hayat. Gürbüz I. (Çev.). İstanbul: Metis Yayınları.

MEB (1996). Örnekleriyle Türkçe sözlük. Ankara: Milli Eğitim Bakanlığı Yayınları

Mead, G. (1934). Mind, self and society. Chicago: University of Chicago Press.

Michikyan, M., Dennis, J. ve Subrahmanyam, K. (2015). Can you guess who I am? Real, ideal, andfalse self-presentation on facebook among emerging adults. Emerging Adulthood, 3(1), 5564.

Mutlu, E. (2012). Illetişim sözlüğ̈̈. Ankara: Sofos.

Neuman, W. Lawrence (2008). Toplumsal araştırma yöntemleri nitel ve nicel yaklaşımlar. Sedef Özge (Çev.), İstanbul: Yayınodası.

Özdemir, B., ve Yıldırım, G. (2019). Dijitalleşen iletişim ortamlarında kimlik inşası ve benlik sunumu: iletişim fakültesi öğrencileri üzerine bir araştırma. e-Journal of New Media/Yeni Medya Elektronik Dergi-eJNM, 3(3), 178-191.

Özdemir, Z. (2015). Sosyal medyada kimlik inşasında yeni akım: özçekim kullanımı. Maltepe Üniversitesi İletişim Fakültesi Dergisi, 2(1), 112-131.

Robins, K. (1999). İmaj, görmenin kültür ve politikası. Türkoğlu, N. (Çev.). İstanbul: Ayrıntı Yayınları.

Solmaz, A., Okumuş, M. ve Okumuş, K. (2015). Dijital oyunlarda müstehcenlik. Uuluslararası Oyun ve Oyuncak Kongresi, Erzurum.

Soydaş, N. (2018). \#illetişim bence dumandan (\#) hashtag'e iletişim. İstanbul: İnkılap Kitabevi.

Sullivan, H. S. (1953). The interpersonal theory of psychiatry. Newyork: Norton Company

Tandaçgüneş, N. (2015). Yeni medya ve reklam. (Ed. Abdullah Özkan, Nilnur Tandaçgüneş, Betül Doğan). Yeni medya ve "oyun" olgusunun değişen kültürel işlevi: Advergaming. 253-281. Istanbul: Derin Yayınları,

Timisi, N. (2003). Yeni iletişim teknolojileri ve demokrasi. Ankara: Dost Yay.

Turkle, S. (1999). Cyberspace and identity. Contemporary Sociology, 28(6), 643-648. 
Wang, H. ve Sun, C.T. (2011). Game reward systems: gaming experiences and social meanings. DiGRA conference, 114, 1-15.

Young, A. L. ve Quan-Haase, A. (2009). Information revelation and internet privacy concerns on social network sites: A case study of Facebook. Proceedings of the Fourth International Conference on Communitiesand Technologies, 265-274.

Zhao, S.,Grasmuck, S. ve Martin, J. (2008). İdentity construction on Facebook digital empowerment in anchored relationships. Computers in Human Behavior, 24(5), 1816-1836. 